\title{
Outcome of chromosomally normal livebirths with increased fetal nuchal translucency at 10-14 weeks' gestation
} Angela F Brady, Pran P Pandya, Bulend Yuksel, Anne Greenough, Michael A Patton,
Kypros H Nicolaides
Medical Genetics Unit, St George's Hospital Medical School, London SW17 ORE, UK

A F Brady

M A Patton

Harris Birthright Research Centre For Fetal Medicine, King's College School of Medicine and Dentistry, London SE5 8RX, UK

P P Pandya

K H Nicolaides

Department of Child Health, King's College School of Medicine and Dentistry, London SE5 8RX, UK

B Yuksel

A Greenough

Correspondence to Dr Brady, The

Kennedy-Galton Centre, Level 8V, Northwick Park Hospital, Watford Road Harrow, Middlesex HAl 3UJ, UK.

Received 1 July 1997 Revised version accepted for publication 26 September 1997

\begin{abstract}
The aim of this study was to determine the outcome of chromosomally normal livebirths with increased fetal nuchal translucency at 10-14 weeks' gestation. Clinical follow up of 89 chromosomally normal livebirths that in fetal life had a minimum nuchal translucency thickness of $3.5 \mathrm{~mm}$ and a comparison group of 302 infants whose fetal nuchal translucency thickness at 10-14 weeks of gestation was less than $3.5 \mathrm{~mm}$ was performed. Major abnormalities, mainly structural defects of the cardiovascular or skeletal systems, were found in $10.1 \%$ (nine of 89 ) of the group with increased translucency, compared to $2 \%$ (five of 302) in those with translucency of less than $3.5 \mathrm{~mm}\left(\chi^{2}=11.9, p<0.001\right)$. Delay in achievement of developmental milestones was observed in one of the infants with increased translucency and in one of the comparison group. The findings of this study show that in chromosomally normal fetuses increased nuchal translucency thickness at 10-14 weeks of gestation is a marker for fetal abnormalities including structural defects and genetic syndromes.

$(\mathcal{H}$ Med Genet 1998;35:222-224)
\end{abstract}

Keywords: fetal nuchal translucency; chromosomal abnormalities

There is a strong association between an abnormal collection of fluid behind the fetal neck (nuchal translucency) at 10-14 weeks of gestation and chromosome abnormalities. ${ }^{1-11}$ Furthermore, in chromosomally normal pregnancies increased nuchal translucency in the first trimester or nuchal fold thickness in the second trimester is associated with a high risk of miscarriage and a wide variety of fetal abnormalities, including cardiovascular, pulmonary, skeletal, metabolic, and haematological defects, as well as congenital infections and single gene disorders, in particular Noonan syndrome. ${ }^{12-17}$

The aim of this study was to investigate the prevalence of congenital anomalies in chromosomally normal livebirths that had a nuchal translucency thickness at 10-14 weeks of gestation of $\geqslant 3.5 \mathrm{~mm}$; this measurement corresponds to the 99th centile of the reference range of translucency thickness at this gestation. $^{1}$
Methods

Clinical follow up (age range 6 months to $31 / 2$ years) was carried out in a consecutive series of 90 chromosomally normal infants, born between January 1991 and October 1994, whose mothers had attended The Harris Birthright Research Centre for Fetal Medicine for ultrasound examination at 10-14 weeks of gestation. The scan had shown that the fetal nuchal translucency thickness was at least $3.5 \mathrm{~mm}$ and chorion villus sampling or amniocentesis showed a normal karyotype. Further antenatal investigations included detailed ultrasound examination and echocardiography at 20 weeks of gestation and maternal serum testing for toxoplasmosis, coxsackie B virus, cytomegalovirus, rubella virus, herpes virus, and parvo B19 virus. The findings in this group were compared to those in 302 chromosomally normal infants whose fetal nuchal translucency thickness at 10-14 weeks of gestation was less than $3.5 \mathrm{~mm}$. This latter group of infants were a group of consecutive cases born during the same period as the study group and they lived near King's College Hospital.

The parents were contacted by telephone and asked whether they would be willing to bring their child to the hospital for clinical assessment. In those that were unable to attend $(n=67)$, details concerning the pregnancy and delivery, early infancy, and the age at which developmental milestones were reached were obtained by telephone. All clinical examinations were carried out either by a clinical geneticist or a paediatrician and features associated with genetic syndromes were specifically looked for. When it was considered necessary $(n=17)$, further information was sought from the patients' general practitioners or hospital consultants.

\section{STATISTICAL ANALYSIS}

Yates' corrected chi-squared test was used to determine the significance of differences in the prevalence of major abnormalities in the group with NT $\geqslant 3.5 \mathrm{~mm}$ compared to those with NT $<3.5 \mathrm{~mm}$ and within the group with NT $\geqslant 3.5 \mathrm{~mm}$ in those where the translucency resolved by 20 weeks of gestation compared to those in which it persisted.

\section{Results}

In the series of 90 chromosomally normal infants with fetal NT $\geqslant 3.5 \mathrm{~mm}$ only one was lost to follow up. Major abnormalities were diagnosed in $10.1 \%$ (nine of 89 ) infants with 
Table 1 Ultrasound findings and major abnormalities in the group with fetal nuchal translucency thickness $\geqslant 3.5 \mathrm{~mm}$ at 10-14 weeks of gestation

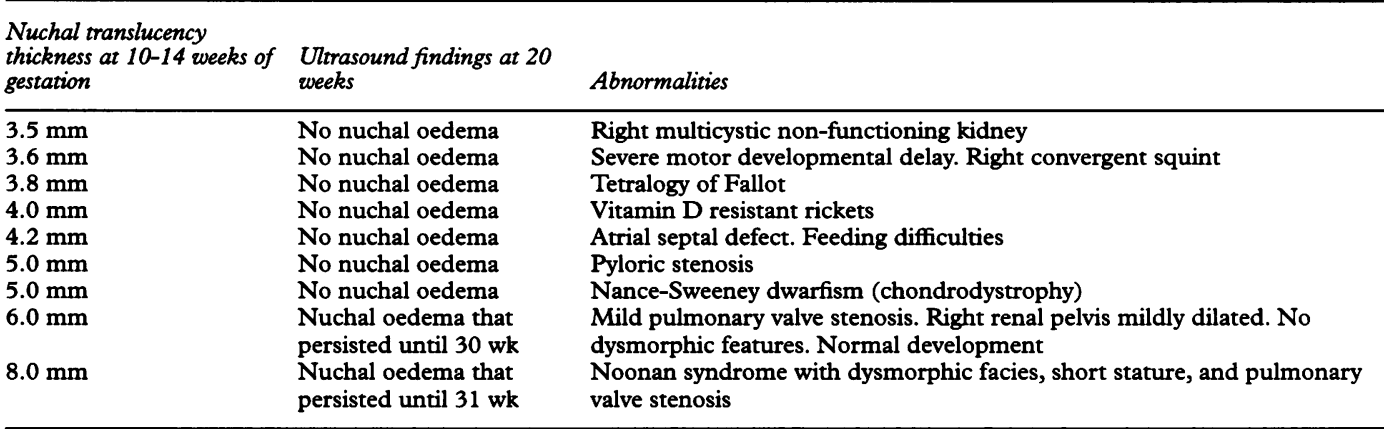

$\mathrm{NT} \geqslant 3.5 \mathrm{~mm}$ (table 1 ), which was significantly higher than the $2 \%$ (five of $302, \chi^{2}=11.9$, $\mathrm{p}<0.001$ ) observed in those with fetal NT $<3.5$ $\mathrm{mm}$. In the latter group there were two cases of ventricular septal defects associated with recurrent respiratory tract infections, and one case each of mild developmental delay, laryngomalacia associated with recurrent respiratory tract infections, and Pierre-Robin syndrome.

Minor abnormalities, including birth marks (for example, strawberry naevi and capillary haemangiomas), umbilical hernias, inguinal hernias, mild hypospadias, undescended testis, hydrocele, positional talipes equinovarus, clinodactyly, or one absent finger, were observed in $14(16 \%)$ of those with fetal NT $\geqslant 3.5 \mathrm{~mm}$ and in $25(8 \%)$ of those with NT $<3.5 \mathrm{~mm}$.

In the group with fetal NT $\geqslant 3.5 \mathrm{~mm}$ at the 10-14 week scan, the translucency resolved before 20 weeks in 75 cases and seven $(9 \%)$ of these had major abnormalities, whereas in the 14 where the translucency evolved into oedema that persisted beyond 20 weeks there were two $(14 \%)\left(\chi^{2}=0.01, p=0.92\right)$ with major abnormalities.

\section{Discussion}

The data in this study suggest that fetal nuchal translucency thickness $\geqslant 3.5 \mathrm{~mm}$ at $10-14$ weeks of gestation in chromosomally normal pregnancies is associated with increased risk for major abnormalities, mainly structural defects of the cardiovascular or skeletal systems. These findings emphasise the need to counsel the parents that fetuses with increased nuchal translucency are not only at risk of chromosomal abnormalities but also of other anomalies including anatomical defects and genetic syndromes.

In a previous study on the outcome of 565 chromosomally normal fetuses with first trimester nuchal translucency 3-9 $\mathrm{mm}$, we reported that about $4 \%$ had structural defects, mainly cardiac, diaphragmatic, renal, and abdominal wall, which is higher than would be expected in an unselected population. ${ }^{12}$ However, the present study is the only one in which detailed genetic and paediatric follow up of infants with increased fetal translucency has been undertaken and the findings compared to those in a group with nuchal translucency $<3.5$ $\mathrm{mm}$. Two previous studies examined a total of 26 chromosomally normal livebirths with increased fetal nuchal translucency (defined as $>2 \mathrm{~mm}$ ); 23 were reported as healthy, two had non-specific dysmorphic features, and one had Noonan syndrome. ${ }^{416}$ In another study of 32 chromosomally normal fetuses with increased nuchal translucency (defined as $>2.5 \mathrm{~mm}$ ), there was one case with persistent hygromas that were successfully repaired at birth and in the other 31 cases the translucency resolved by 20 weeks and all babies were healthy at birth; follow up examination at 12 months showed normal growth and development in all infants. ${ }^{17} \mathrm{~A}$ recent study examining the outcome of 28 pregnancies associated with NT thickness $>3 \mathrm{~mm}$ at $10-15$ weeks and normal karyotype indicated that a more pronounced NT thickness is associated with a higher incidence of structural anomalies and a poorer fetal outcome. ${ }^{18}$

In our study there was no significant increase in the number of major abnormalities found in the group where the NT persisted beyond 20 weeks compared to those pregnancies where it resolved. However, it is acknowledged that the number of cases examined was too small to reach a conclusion that the outcome of pregnancies associated with nuchal translucency is not related to the time at which the thickening resolves.

It is well recognised that Noonan syndrome is associated with abnormal accumulation of nuchal fluid and hydrops fetalis. ${ }^{19}$ Witt et a ${ }^{20}$ reported nine cases with lymphoedema and concluded that the major source was generalised dysplasia of the lymphatic vessels. Bennacerraf et $a l^{14}$ reported on the prenatal sonographic features in four infants with Noonan syndrome and all four fetuses had cystic hygromata. However, the diagnosis of Noonan syndrome cannot be predicted from the time of resolution of the abnormal nuchal fluid. Both in our case and two previously reported ones resolution did not occur until the third trimester. ${ }^{21}$ In contrast, Trauffer et $a l^{16}$ reported one case where resolution occurred before 20 weeks.

The findings of this study show that in chromosomally normal fetuses increased nuchal translucency thickness at 10-14 weeks of gestation is a marker for fetal abnormalities including structural defects and genetic syndromes. Consequently, parents should be counselled that in the presence of this sonographic marker the fetus is not only at risk of chromosomal abnormalities but also of other defects. Therefore, in addition to offering the parents the option for fetal karyotyping, the finding of 
increased translucency should stimulate the search for other fetal defects by detailed ultrasonography and postnatal paediatric follow up should be arranged.

The authors would like to thank the patients for all their help with this study, and The Birth Defects Foundation and The Medical Research Council for financial support.

1 Nicolaides KH, Azar G, Byrne D, Mansur C, Marks K. Fetal nuchal translucency: ultrasound screening for chromosomal defects in first trimester of pregnancy. $B M F$ 1992;304:867-9.

2 Shulman LP, Emerson DS, Felker R, Phillips OP, Simpson $\pi$, Elias $S$. High frequency of cytogenetic abnormalities in fetuses with cystic hyoroma diagnosed in the first trimester. Obstet Gynecol 1992;80:80-2.

3 Schulte-Vallentin M, Schindler H. Non-echogenic oedema as a marker in trisomy 21 screening. Lancet 1992;339:1053.

4 Johnson MP, Johnson A, Holzgreve W, et al. First-trimester sohnson MP, Johnson A, Holzgreve W, et al. First-trimester simple hygroma: caur

5 van Zalen-Sprock RM, van Vugt JMG, van Geijn HP. Nonechogenic nuchal oedema as a marker in trisomy 21 screening. Lancet 1992;13:1480-1.

6 Ville Y, Lalondrelle C, Doumere S, et al. First-trimester diagnosis of nuchal anomalies: significance and fetal outcome. Ultrasound Obstet Gynecol 1992;2:314-16.

7 Wilson RD, Venir N, Farquharson DF. Fetal nuchal fluid physiological or pathological? - in pregnancies less than 17 menstrual weeks. Prenat Diagn 1992;12:755-63.

8 Nadel A, Bromley B, Benacerraf BR. Nuchal thickening or cystic hygromas in first- and early second-trimester fetuses: prognosis and outcome. Obstet Gynecol 1993;82:43-8.

9 Hewitt B. Nuchal translucency in the first trimester. Aust NZ Obstet Gynaecol 1993;33:389-91.

10 Cullen MT, Gabrielli S, Green J, et al. Diagnosis and significance of cystic hygroma in the first trimester. Prenat Diagn 1990;10:643-51.
11 Savoldelli G, Binkert F, Achermann J, Schmid W. Ultrasound screening for chromosomal anomalies in the first trimester of pregnancy. Prenat Diagn 1993;13:513-18.

12 Pandya PP, Kondylios A, Hilbert L, Snijders RJM Nicolaides KH. Chromosomal defects and outcome in 1,015 fetuses with increased nuchal translucency. Ultrasound Obstet Gynecol 1995;5:15-19.

13 Nicolaides KH, Azar G, Snijders RJM, Gosden CM. Fetal nuchal oedema: associated malformations and chromosomal defects. Fetal Diagn Ther 1992;7:123-31.

14 Benacerraf BR, Greene MF, Holmes LB. The prenatal sonographic features of Noonan's syndrome. F Ultrasound Med 1989;8:59-63.

15 Hyett J, Moscoso G, Papapanagiotou G, Perdu M, Nicolaides $\mathrm{K}$. Abnormalities of the heart and great arterie in chromosomally normal fetuses with increased nuchal translucency thickness at 11-13 weeks of gestation. Ultrasound Obstet Gynecol 1996;7:245-50.

16 Trauffer ML, Anderson CE, Johnson A, Heeger S, Morgan P, Wapner RJ. The natural history of euploid pregnancies with first-trimester cystic hygromas. Am f Obstet Gynecol 1994;170:1279-84.

17 Shulman LP, Emerson DS, Grevengood C, et al. Clinical course and outcome of fetuses with isolated cystic nuchal lesions and normal karyotypes detected in the first trimester. Am $\mathcal{F}$ Obstet Gynecol 1994;171:1278-81.

18 Cha'ban FK, van Splunder P, Los FJ, et al. Fetal outcome in nuchal tranclucency with emphasis on normal fetal karyotype. Prenat Diagn 1996;16:537-41.

19 Chevenak FA, Isaacson G, Blakemore KJ, et al. Fetal cystic hygroma: cause and natural history. $N$ Engl $f \mathrm{Med}$ 1983;309:822-5.

20 Witt DR, Hoyme HE, Zonana J, et al. Lymphedema in Noonan syndrome: clues to pathogenesis and prenatal diagnosis and review of the literature. Am $\mathcal{f}$ Med Genet 1987;27:841-56.

21 Langer JC, Fitzgerald PG, Desa D, et al. Cervical cystic hygroma in the fetus: clinical spectrum and outcome. Pediatr Surg 1990;25:58-61. 